\title{
Employment Opportunities of Daily Wages Construction Labour at Camp Road Junction
}

\author{
K.Venkatraman, P.Dayakar, R.Venkatakrishnaiah, A.Mani
}

\begin{abstract}
In construction field the labours are the back bone of the site work as well as all sort of work which is executed in the construction. Labours plays a major role in deciding the success of the project and the labour factor also plays a major role in time deciding of the completion of the project. As there is a requirement of more number of labours the wages provided to them are been less when compared to other state. The labours from other state is also are employed more when compare to the native state labour though they are paid less when compared to the native state labours. In this study a junction where the labours are more in numbers are chosen for the surveying from them and with the details collected from them are been used to analysis their current scenario and their present situation in the construction field. In this study the maximum labours chosen for survey are mason are of $70 \%$ from the total survey. Further, the paper brings up that the expansion in labor profitability has not been converted into expanded development in genuine wages, especially for easygoing specialists. The Minimum wages Act is inadequately actualized, especially in rustic zones. Subsequently, there is a need to make game plans for the compelling execution of this Act. In general, the paper contends that the low degree of wages and the expanding wage differential crosswise over various portions of the work market have brought about across the board destitution among specialists, especially development works.
\end{abstract}

Key words: Labour Productivity, Implementation

\section{INTRODUCTION}

In construction field labours play a major role in regulating the work without any disturbance. In a site of development enlists countless development specialists other than customary workers, on contract through a middle person (for example contractor). The momentary work results to: unscheduled turnover in an association, low staff confidence and low profitability.

Transient business influenced efficiency of staff in the association since a ton of time and exertion was utilized in preparing new representatives as their turnover was high.(Hillary Thomas Wandera). Regarding compensation,

Revised Manuscript Received on July 22, 2019

K.Venkatraman, Assistant Professor, Department of Civil Engineering, Bharath Institute Of Education And Research, Chennai, Tamil Nadu Email: venkatraman.civil@bharathuniv.ac.in

P.Dayakar Associate Professor, Department of Civil Engineering, Bharath Institute Of Education And Research, Chennai , Tamil Nadu Email: dayakarpitti@yahoo.co.in

Dr.R.Venkatakrishnaiah, Associate Professor, Department of Civil Engineering, Bharath Institute Of Education And Research, Chennai , Tamil Nadu Email: venkatapec@gmail.com

Dr.A. Mani, Professor, Department of Civil Engineering, Bharath Institute Of Education And Research, Chennai , Tamil Nadu Email: maniathi57@yahoo.in
62 respondents speaking to $13.3 \%$ of them unequivocally differ that they are paid pay at the very least the lowest pay permitted by law, 54 of them speaking to $11.5 \%$ differ that they get pay at the very least the lowest pay permitted by law, 19 respondent speaking to $4.1 \%$ didn't know, 190 of them speaking to $40.6 \%$ concurred and 143 respondents speaking to 30.6 emphatically agreed(Humphrey Danso)Supervision costs under every day contracts, assuming any, fortify the prevalence of piece-rate contracts.

Second, piece-rate contracts might be 'beneficial contracts', which exist together with every day pay contracts on the grounds that the advantages of piece rate contracts referenced above are accomplished at some expense to the business as far as assignment quality so day by day pay contracts are not by any means repetitive. (Jean-Marie Baland). The document serves as a platform for deciding the position of the labour in current scenario. The study completely analyses the industry characteristics, value chain, cost structure and demographic profile of urban building construction labour in Camp road junction.

\section{FIELD STUDY}

From the field study which is made with the different category of people in the camp road junction of Tambaram. This study shows a clear state on the management and the condition of the labour in the current scenario. In case of camp road junction it is a main meeting point of all the construction labours in which there are many constructions going around the labours are also categorized according to their age, experience and specialization in the construction field. The below details are collected from the data collection from the field and which is been enumerates in the below report.

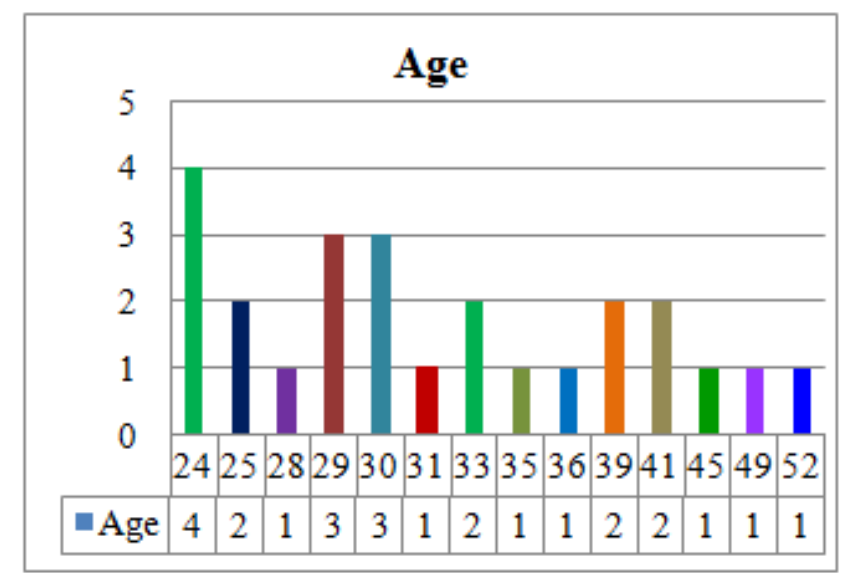

Fig.1 Age of the Labours Surveyed 
Fig 1. Enumerates the different age category of people in the construction field and from them the survey is started and from the discretising it can be stated that the labours who are of 24 age is in more number when compared to the other age categorized labour. It can also be stated that the labours who are more than 50 age group is less in numbers when compared to the other age group. It is also confines that the labours of more than 28 age group are been getting jobs regularly in a consecutive gap and where as other area been place seasonally.

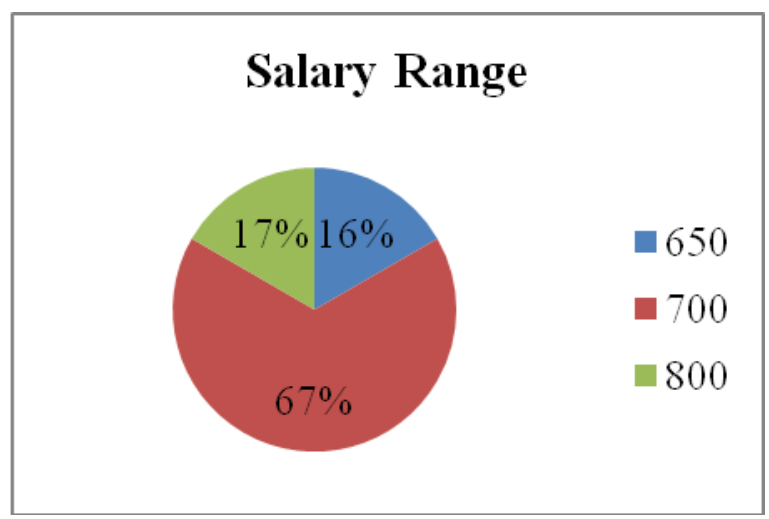

Fig.2 Salary Range Surveyed

Fig 2. Emphases that the labours salary wages of different age category of people in the construction field and from them the survey is started and from the discretising it can be stated that the labours whose salary ranges from 500 to 900 Rs based on their specialization and experience of work in the construction field. From the survey it can be confined that the labours who are maximum salary ranges from the Rs 700 and most of the labours are been paid to the same.

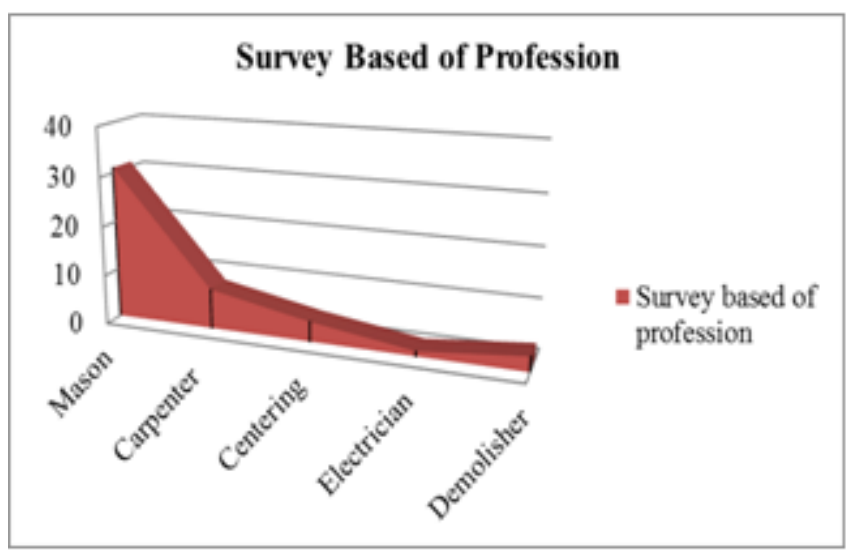

Fig.3 Labours Survey based on Profession

Fig. 3 In this study the survey extracted is maximum from the mason. In which the result extract shows the survey is also confined with the other labours from different field in construction. Whereas the construction is mainly depended on the mason, so that it helps to extract the results of the survey clearly. More than $70 \%$ of the labour is mason, $20 \%$ of carpenter, $5 \%$ of electrician and centering and $5 \%$ of labour is of demolisher

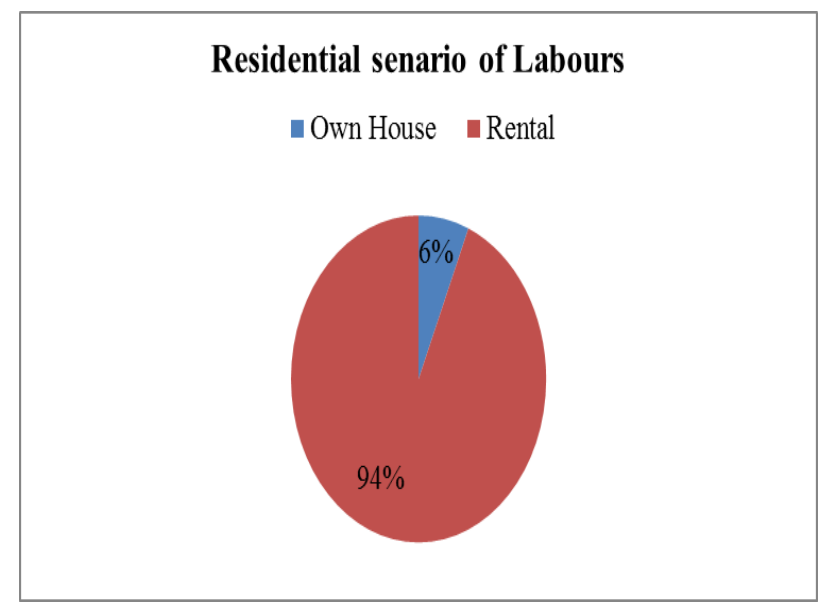

Fig.4 Residential scenario of the labours

Fig.4 In this survey most of the labours are staying in rental house. $94 \%$ of labours stay in rental house and $6 \%$ of the labours are in the own house this survey says that most of labours are in the rental house. So we conclude that most of the labours are under the poverty line so most of the labours are in rented house and only few is in own house.

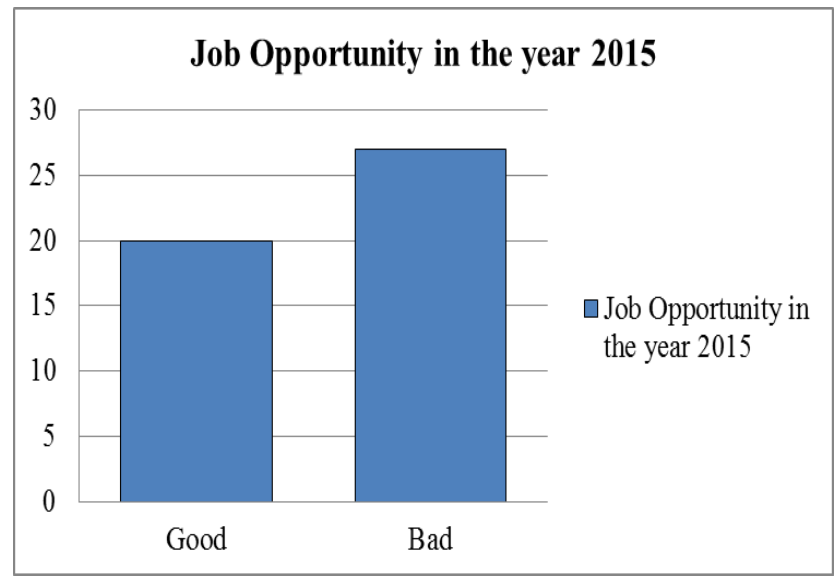

Fig.5 Job opportunity -2015

Fig.5 From this graph it come to know that during the year 2015 most of the labour job opportunity is bad and only some of the labours feel that their job opportunities are good. From the survey it can be stated that the year 2015 is fall in construction field and less job opportunities in civil field most of labours

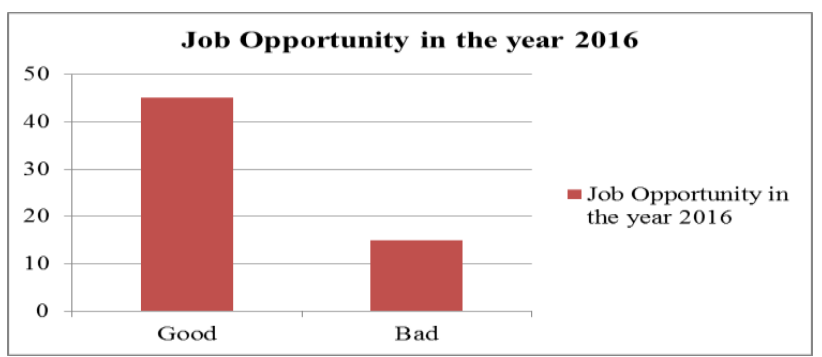

Fig.6 Job opportunity -2016 
Fig.6 From this graph it can be stated that the job opportunity is better than the year 2015 when compare to the chart of 2015 the year 2016 provide a good job opportunity. During the year 2016 the job opportunity is seems to be better when compared to the year 2016. It shows the year 2016 provided a job opportunity to the labour in the construction field.

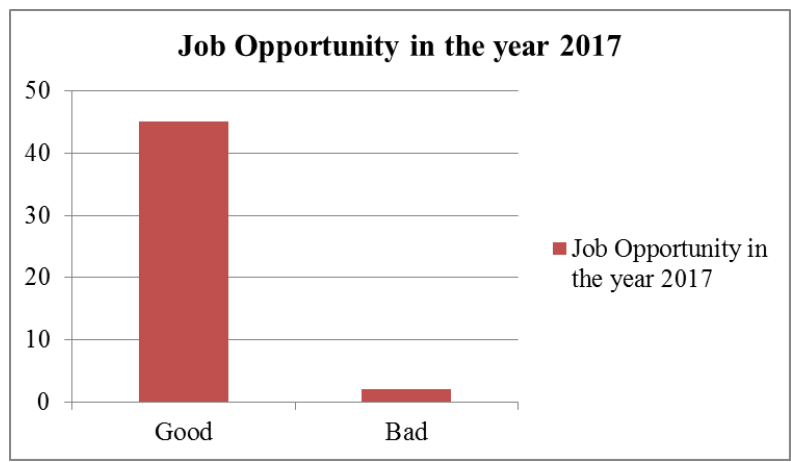

Fig.7 Job opportunity -2017

Fig. 7 shows a drastic development in the construction field in the year 2017 so that the graph shows the good development in the year 2017. From the past two year the labour opportunity where less when compare to the year 2017. In the year 2017 provides a good job opportunity for the labour when compare to the past two year.

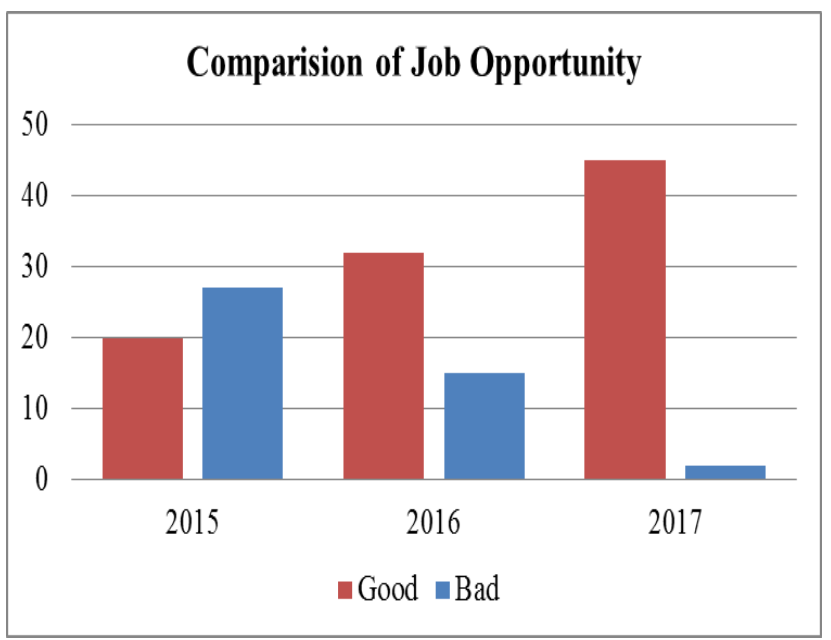

Fig.8 Job opportunity of Labours

From this survey it could be described that the most of job required of labours is more in the year 2017 when compared to the year 2015 and 2016. The chart emphasis that the construction industry is boosted in the year 2017 and the labours revised salary according to the government of the Tamilnadu in the year 2016. So that the opportunity of the labour in the construction field is more.

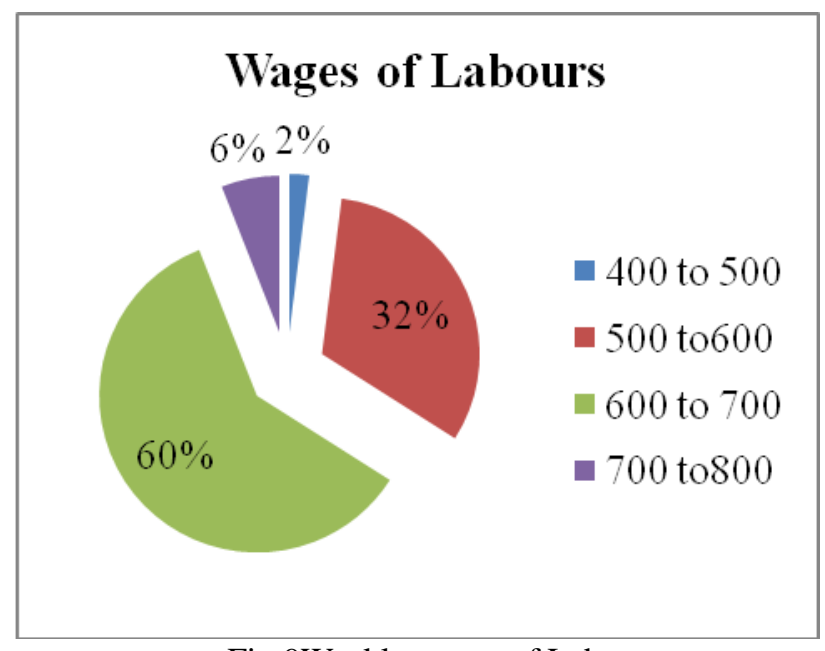

Fig.9Weekly wages of Labour

From the fig 9. It can be stated that the weekly wages for the labour are more that 500Rs in which it is connected to the monthly wages of the labours from the survey more than $75 \%$ of the labours are been paid more than 500Rs in weekly bases. Whereas from the study the labours weekly wages of 500 to 600 rs are of $32 \%$ and the labours weekly wages of 600 to 700 rs are of $60 \%$ and the labours weekly wages of 700 to $800 \mathrm{rs}$ are of $6 \%$ and the labours weekly wages of 400 to $500 \mathrm{rs}$ are of $2 \%$.

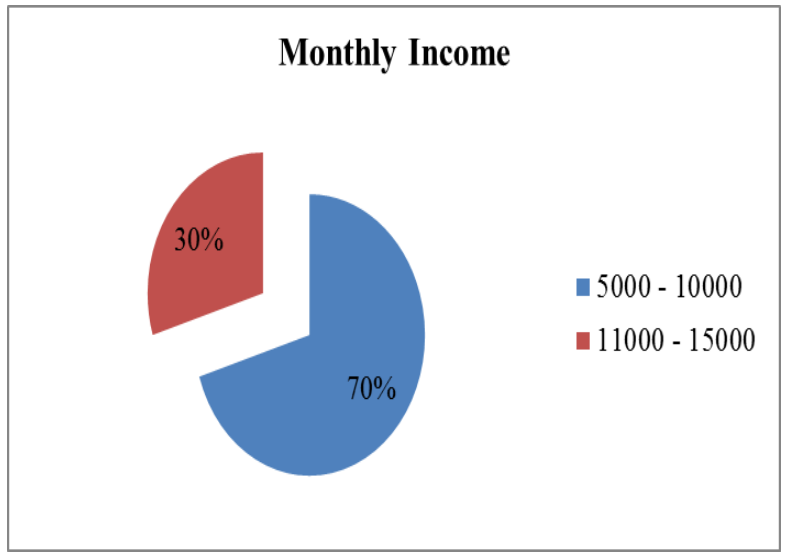

Fig.10Monthly income of the Labours

In the current situation the monthly income of the labours are more in category of (11000- 15000). 30\% of labours monthly income are $(5000-10000)$ and $70 \%$ of labours monthly income are $(11000-15000)$. From the study it is observed that the labour that are waged more 5000 Rs are of $70 \%$ and the labours more 10000 rs are $30 \%$ according to their profession. It can also be stated that from the government chart it emphasis that as the revised wages of the labour are some of the effective measure to improve their life.

\section{CONCLUSION}

From the study it can be concluded that the pattern of wages and earnings in different sectors reveals that employment and wage growth have not been simultaneous. The sectors of mass employment and higher employment growth have witnessed the slowest growth

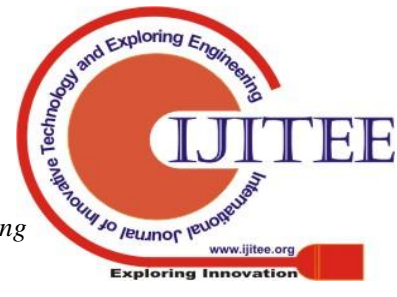




\section{Employment Opportunities Of Daily Wages Construction Labour At Camp Road Junction}

in wages, while the sectors of low employment and slower employment growth have witnessed high wage growth. This has led to the further widening of the existing wage in equalities across sectors. One of the most important reasons for this is that the majority of workers in the construction are of where daily wages/ earnings are very low.

It is also concluded that the after revising the labours wages in the construction field by the state governance it shows some improvement in the wages and also their monthly income is improved by the revised state of wages. Guaranteeing least wages in country regions and improving working conditions in the urban casual area must be taken up on a need premise with the goal that specialists in these areas can receive the rewards of expanded work efficiency all in all and win a good occupation specifically. From the year 2015 to 2017 it can be confined that the position of the labours and the daily wages of labour are improved by $50 \%$ of 2015 year.

\section{REFERENCES}

1. Iyappan L., Dayakar P., Identification of landslide prone zone for coonoortalukusing spatial technology, International Journal of Applied Engineering Research,V-9,I-22,PP-5724-5732,Y-2014.

2. Kumar J., Sathish Kumar K., Dayakar P.,Effect of microsilica on high strength concrete, International Journal of Applied Engineering Research,V-9,I-22,PP-5427-5432,Y-2014.

3. Dayakar P., Vijay Ruthrapathi G., Prakesh J., Management of bio-medical waste, International Journal of Applied Engineering Research,V-9,I-22,PP-5518-5526,Y-2014.

4. Swaminathan N., Dayakar P., Resource optimization in construction project, International Journal of Applied Engineering Research,V-9,I-22,PP-5546-5551,Y-2014.

5. Venkat Raman K., Dayakar P., Raju K.V.B.,An experimental study on effect of cone diameters in penetration test on sandy soil, International Journal of Civil Engineering and Technology,V-8,I-8,PP-1581-1588,Y-2017.

6. Saritha B., Chockalingam M.P.,Photodradation of malachite green DYE using TIO2/activated carbon composite,International Journal of Civil Engineering and Technology,V-8,I-8,PP-156-163,Y-2017

7. Shendge R.B., Chockalingam M.P., Saritha B., Ambica A.,Swat modelling for sediment yield: A case study of Ujjani reservoir in Maharashtra, India,International Journal of Civil Engineering and Technology,V-9,I-1,PP-245-252,Y-2018

8. Chockalingam M.P., Balamurgan V.,Modernisation of an existing urban road-sector in Chennai, a case study report,International Journal of Civil Engineering and Technology,V-8,I-8,PP-1457-1467,Y-2017

9. Saritha B., Chockalingam M.P.,Adsorption study on removal of basic dye by modified coconut shell adsorbent, International Journal of Civil Engineering and Technology,V-8,I-8,PP-1370-1374,Y-2017

10. Saritha B., Chockalingam M.P.,Adsorptive removal of heavy metal chromium from aqueous medium using modified natural adsorbent,International Journal of Civil Engineering and Technology,V-8,I-8,PP-1382-1387,Y-2017

11. Chockalingam M.P., Palanivelraja S.,Retrospective analysis of a theoretical model used for forecasting future air quality near the north Chennai thermal power plant,International Journal of Civil Engineering and Technology,V-8,I-8,PP-1457-1467,Y-2017

12. Saritha B., Chockalingam M.P.,Photodegradation of methylene blue dye in aqueous medium by $\mathrm{Fe}-\mathrm{AC} / \mathrm{TiO} 2$ Composite,Nature Environment and Pollution Technology,V-17,I-4,PP-1259-1265,Y-2018

13. Shendge R.B., Chockalingam M.P., Kaviya B., Ambica A.,Estimates of potential evapotranspiration rates by three methods in upper Bhima Basin, In Maharashtra, India,International Journal of Civil Engineering and Technology,V-9,I-2,PP-475-480,Y-2018

14. Shendge R.B., Chockalingam M.P.,The soil and water assessment tool for Ujjani Reservoir,International Journal of Mechanical Engineering and Technology,V-9,I-2,PP-354-359,Y-2018

15. Shendge R.B., Chockalingam M.P.,A review on soil and water assessment tool,International Journal of Mechanical Engineering and Technology,V-9,I-2,PP-347-353,Y-2018
16. Sachithanandam P., Meikandaan T.P., Srividya T.,Steel framed multi storey residential building analysis and design,International Journal of Applied Engineering Research,V-9,I-22,PP-5527-5529,Y-2014

17. Meikandaan T.P., Ramachandra Murthy A.,Study of damaged RC beams repaired by bonding of CFRP laminates,International Journal of Civil Engineering and Technology,V-8,I-2,PP-470-486,Y-2017

18. Meikandaan T.P., Ramachandra Murthy A.,Retrofittng of reinforced concrete beams using GFRP overlays,International Journal of Civil Engineering and Technology,V-8,I-2,PP-423-439,Y-2017

19. Meikandaan T.P., Ramachandra Murthy A.,Flexural behaviour of RC beam wrapped with GFRP sheets,International Journal of Civil Engineering and Technology,V-8,I-2,PP-452-469,Y-2017

20. Meikandaan T.P., Murthy A.R.,Experimental study on strengthening of rc beams using glass Fiber,International Journal of Civil Engineering and Technology,V-9,I-11,PP-959-965,Y-2018

21. Meikandaan T.P., Hemapriya M.,Use of glass FRP sheets as external flexural reinforcement in RCC Beam,International Journal of Civil Engineering and Technology,V-8,I-8,PP-1485-1501,Y-2017

22. Saraswathy R., Saritha B.,Planning of integrated satellite township at Thirumazhisai,International Journal of Applied Engineering Research,V-9,I-22,PP-5558-5560,Y-2014

23. Saritha B., Ilayaraja K., Eqyaabal Z.,Geo textiles and geo synthetics for soil reinforcement,International Journal of Applied Engineering Research,V-9,I-22,PP-5533-5536,Y-2014

24. Ambica A., Saritha B., Changring G., Singh N B., Rajen M., Salman Md.,Analysis of groundwater quality in and around Tambaram taluk, Kancheepuram district,International Journal of Civil Engineering and Technology,V-8,I-8,PP-1362-1369,Y-2017

25. Arunya A., Sarayu K., Ramachandra Murthy A., Iyer N.R.,Enhancement of durability properties of bioconcrete incorporated with nano silica,International Journal of Civil Engineering and Technology,V-8,I-8,PP-1388-1394,Y-2017

26. Ilayaraja K., Krishnamurthy R.R., Jayaprakash M., Velmurugan P.M. Muthuraj S.,Characterization of the 26 December 2004 tsunami deposits in Andaman Islands (Bay of Bengal, India),Environmental Earth Sciences,V-66,I-8,PP-2459-2476,Y-2012

27. Ilayaraja K.,Morphometric parameters of micro watershed in Paravanar sub-basin, Cuddalore District,International Journal of Civil Engineering and Technology,V-8,I-8,PP-1444-1449,Y-2017

28. Ilayaraja K., Singh R.K., Rana N., Chauhan R., Sutradhar N.,Site suitability assessment for residential areas in south Chennai region using remote sensing and GIS techniques,International Journal of Civil Engineering and Technology,V-8,I-8,PP-1468-1475,Y-2017

29. Ilayaraja K., Reza W., Kumar V., Paul S., Chowdhary R.,Estimation of land surface temperature of Chennai metropolitan area using Landsat images,International Journal of Civil Engineering and Technology,V-8,I-8,PP-1450-1456,Y-2017

30. Chitra R.,Experimental study on beam using steel fiber and latex,International Journal of Civil Engineering and Technology,V-8,I-8,PP-1395-1403,Y-2017

31. Chitra R.,Analysis of traffic and management at Kovilambakkam intersection,International Journal of Civil Engineering and Technology,V-8,I-8,PP-1433-1443,Y-2017

32. Aswathy M.,Experimental study on light weight foamed concrete,International Journal of Civil Engineering and Technology,V-8,I-8,PP-1404-1412,Y-2017

33. Aswathy M.,Wastewater treatment using constructed wetland with water lettuce (Eichornia Crasipies),International Journal of Civil Engineering and Technology,V-8,I-8,PP-1413-1421,Y-2017

34. Kiruthiga K., Anandh K.S., Gunasekaran K, Assessment of influencing factors on improving effectiveness and productivity of construction engineers, 2015, International Journal of Applied Engineering Research, V - 10,I -17,p -13849-13854 


\section{AUTHORS PROFILE}

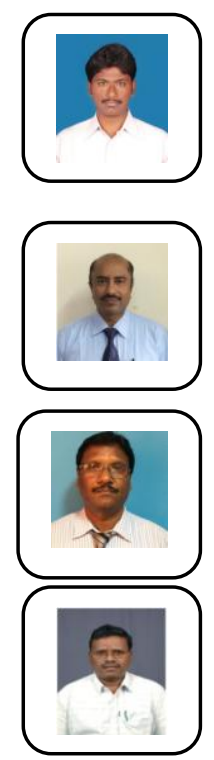

K.Venkatraman Assistant professor, Department of Civil Engineering, Bharath Institute of Higher Education and Research, Chennai, India

P.Dayakar ,Associate professor, Department of Civil Engineering, Bharath Institute of Higher Education and Research, Chennai, India

Dr.R.Venkatakrishnaiah Associate professor Department of Civil Engineering, Bharath Institute of Higher Education and Research, Chennai, India

Dr.A.Mani Professor, Department of Civil Engineering, Bharath Institute of Higher Education and Research, Chennai, India 